\title{
On the Political Economy of State Corporate Tax Reforms in the U.S.
}

\author{
Eliakim Kakpo ${ }^{1, *}$ \\ ${ }^{1}$ Post-doctoral researcher at CESAER-INRA, France \\ *Corresponding author: E-mail: Eliakim.Kakpo@inra.fr
}

Received: July 8, 2019 Accepted: August 9, 2019 Published: August 25, 2019

doi: 10.5296/rae.v11i3.15043ＵRL: https://doi.org/10.5296/rae.v11i3.15043

\begin{abstract}
This paper discusses the political economy of U.S. state corporate tax reforms. Using a unique dataset of state effective corporate tax rates over the period 1969-2015, I observe that business tax changes are associated with tax competition, swings in economic cycles, and left-right political ideology. In contrast, long-term debt and budgetary pressures do not correlate with state corporate tax policies. Moreover, I document a regional heterogeneity and notice a slowdown in state tax changes after the Federal Reform Act of 1986. These findings matter for the empirics of corporate tax incidence, which is increasingly concerned with the endogeneity between tax reforms and other economic developments.
\end{abstract}

Keywords: Tax reform, Tax competition, Tax incidence, State public debt, State budget 


\section{Introduction}

Over the last few decades, several U.S. states have lowered their tax rates on business profits. If the incidence of such policies has received a great deal of attention, very few empirical works have explored the motivations behind such reforms. Though long-term growth, globalization, public debt (Swank and Steinmo, 2002, Tanzi, 1995), tax competition, domestic business cycle, and regional shocks have all been suggested as potential drivers of national corporate tax reforms, no exhaustive investigation has been done at the state level. This consideration is critical for the consistency of empirical estimates of state corporate tax effects. I articulate in this paper that the major source of endogeneity when studying the incidence of state corporate tax changes in the U.S. results from spatial correlation due to tax competition, as well as political ideology that could itself affect other unobservables that determine economic outcomes.

Specifically, I conclude that the political affiliation of the party in control of a state's institutions correlates with corporate tax changes even after controlling for economic trends. I also observe that the average rate of neighboring states and pre-existing economic conditions affect incentives to change the business tax. In contrast, long-term debt and budgetary pressures do not seem to bear any significant relationship with state corporate tax reform. Finally, I document a heterogeneity in the frequency of tax changes across regions and notice a slowdown in state corporate tax increases after the federal tax reform of 1986.

Early classical economists have long defended that the mobile nature of capital assets poses several challenges to public authorities seeking to raise taxes to finance social obligations. This argument was later confirmed by Harberger (1962) and a number of public economists (Randolph, 2006; Reveendra, 1975; Gravelle, 2006) who set to investigate the incidence of the corporate tax in a basic two-sector general equilibrium model. The mechanics at the source of these groundbreaking theoretical works suggest that the burden of a tax change would fall predominantly on the less mobile factor (i.e.) labor.

The empirical literature (Carroll et al., 2010; Hassett et al., 2006; Vartia, 2008) provided further evidence in support of this prediction. As a consequence, policymakers grew skeptical of the economic benefits of taxes on capital returns. However, many of the works seeking to measure the corporate tax incidence are plagued with identification issues due to the potential endogeneity between policy reforms and pre-existing trends in outcomes of interest. Understanding the political economy of state corporate tax reforms is critical for the design of a suitable empirical strategy when estimating this causal effect.

The most cited sources of endogeneity between corporate tax policies and labor market outcomes originate from the increasing wave of globalization and the rise of social expenditures in advanced economies. The former increased the bargaining power of capital assets, which in turn exerted downward pressure on effective corporate tax rates around the globe. In contrast, the rise in social obligations and the growing presence of the public sector in rich economies tend to pull tax rates upward. Both sources undoubtedly affect the demand for labor by firms as well as the incentive to work by households. This is compounded by the current debt-adverse environment which limits the ability of many governments, specially at 
the sub-national level, to borrow on financial markets to offset the upheavals of the business cycle. These considerations highlight the trade-off at the center of the corporate tax debate, and the need to consider endogeneity when measuring the incidence of corporate taxation.

Alternatively, there is mounting evidence suggesting a rise of tax competition across U.S. jurisdictions to attract private investments and stimulate economic growth (Chirinko and Wilson, 2017). Secular stagnation shifted the policy debate to low-productivity growth, contributing to the adoption of tax expenditures by several state and local governments to attract corporations and promote capital investment. Corporate taxation is part of an arsenal of instruments at the disposal of policymakers to spur long-term economic growth. This implies that corporate tax rates in neighboring states could be useful predictors of policymakers' incentives to amend the business tax code.

Finally, ever-decreasing levels of corporate tax collections at the national and local levels contributed to the re-emergence of a widespread interest in tax reform. The main goal is to reduce inefficiencies and eliminate incentives to minimize tax liabilities through profit-shifting (Klassen et al., 2012; Mintz and Smart, 2003). All ideologies across the political spectrum increasingly favor some changes to the corporate tax system. Liberal policymakers would like to close tax loopholes while conservatives defend that high corporate tax rates impede capital formation, employment, and growth.

In so far as the decreasing share of corporate income taxes in public revenue is driven by globalization and its implications on the fungibility of capital; one should expect the relationship between corporate tax rates and the usual outcomes of interest to be confounded by other forces. Also, since developments with regards to openness, trade and financial liberalization are generally set at the federal level; incentives to amend the corporate tax code in response to these forces should remain identical across states. I address this consideration with time specific effects in most regressions.

The goal of this paper is to provide a thorough description of the political economy of corporate tax reforms at the state level in the U.S. I exploit a unique historical record of state effective corporate tax rates over the period 1969-2014 which was initially compiled by Chirinko and Wilson up until 2008. First, I extended this dataset to 2014 using information in the "Books of States" reports provided by the Council of State Governments. I then observed that state corporate tax changes are associated with tax rates in neighboring states, developments in tax reforms at the federal level, and the party affiliation of a state's political control. In contrast, movements in the business cycle and long-term debt do not predict corporate tax changes. I also observe a stark heterogeneity in the frequency of business tax reforms across regions.

The rest of the paper is organized as follows. Section 2 briefly reviews the relevant literature, with a focus on the potential determinants of tax policy reforms at the national level. Section 3 describes the structure of state corporate taxation in the U.S. and analyzes recent trends in state corporate tax hikes and cuts, while Section 4 presents the data sources. Section 5 discusses the methodology and section 6 analyzes the main findings. Section 7 highlights the implications for the empirical literature while section 8 concludes the analysis. 


\section{Relevant Literature}

The political economy of tax reforms has been the subject of a wealth of scholarly papers, books, and news articles. Though a great deal of this interest has captured the attention of political scientists, a growing body of development research seeks to understand the sociopolitical institutions at the source of tax reforms. Tax policy has always been suggested as a key instrument for development (Tanzi and Zee, 2000; Bird R.M., 1992; Easterly and Rebelo, 1993). The theoretical baseline underlying these analyses derives from the neoclassical Solow-Swan growth model and its implications for capital accumulation, growth, and development. These authors defend that taxes on certain goods or assets could impede investment and limit economic growth in the long-run.

The overwhelming consensus in this literature supports that taxes are vital for long-run economic prosperity. Personal and corporate income tax, value-added taxes on imported investment goods and investment tax credits can all be used to promote saving, investment, and growth (Tanzi and Zee, 2000; Ito and Krueger, 1992). Notwithstanding the fact that these predictions predominantly focus on developing nations, the same mechanics might be relevant for several advanced economies due to the current environment of low productivity growth and secular stagnation. The corporate tax, in particular, affects the user cost of capital and could alter investment incentives in the long-run. This implies that long-term economic growth could be an important motivation for corporate tax reforms both at the national and local level.

Other often cited determinants of tax policy relate to the business cycle. It is well documented that during periods of economic recession, automatic stabilizers would negatively affect public revenue and income tax collection while the opposite is likely to occur in periods of booms. In advanced economies, policymakers are generally prone to adopting countercyclical fiscal measures to offset the adverse effects of economic downturns. These include personal and business income tax relief but also investment credits and several provisions related to capital accumulation. The empirical evidence on the effectiveness of such Keynesian policies remains a longstanding controversial debate (Chodorow-Reich et al., 2012). Several Neoclassical economists have challenged the notion that public expenditures could be used to smooth the upheavals of the business cycle. Even though the federal corporate tax code did not feature dramatic changes over time, on average five U.S. states amend their corporate tax structure every year and regional and local economic cycles might influence such decisions.

Another set of reasons why a state would alter its tax code relates to globalization and the growing competition between jurisdictions both within and across countries to attract businesses. As evidenced by a series of papers (Altshuler et al., 2015; Devereux et al., 2008), countries are engaged in a race to the bottom with regards to business tax rates. Strategic tax competition has also been documented between states and counties in the U.S. (Brueckner, 2003). The theoretical tax competition literature can be categorized by two sets of results. The generally accepted consensus of a positive tax reaction function - tax rates of a jurisdiction would move in the same direction as those of competing counterparts - has been recently challenged by a series of papers (Mintz and Tulkens, 2006; Wilson and Janeba, 2005) that explored the possibility of a negative or uncertain tax reaction slope. However, the empirical 


\section{Mll Macrothink}

literature heavily favors the dominant view of an increasing "race to the bottom" between countries and states.

Alternatively, long-term debt has been suggested as a potential driver of corporate tax policy. How governments respond to debt accumulation remains a controversial subject within the macroeconomic literature. Some argue that in the face of a growing debt, policymakers should adopt corrective measures that involve meaningful increases in tax rates (Bohn, 1998). This line of thought finds support in the literature of optimal government finance, which also recommends moderate budget deficits. Deviations from the stationary debt equilibrium should be offset by reduced social obligations or increases in tax rates; suggesting that state corporate tax reforms could be driven by debt considerations.

Finally, ideas such as economic theories influence policies and social outcomes. The neoliberal order that emerged during the 1980s emphasized the importance of individual choice, limited government and private markets for prosperity. This shifted the political debate to the role and extent of government presence in the economy, especially in rich countries. A few publications (Campbell, 1998) have suggested that the "Reagan Revolution" of the 1980s may have tilted all shades of the political spectrum towards market-friendly policies.

The sources of this expansion of free-market ideas during the early 1980s have also received a substantial wealth of research attention. If ideas influence policy agenda and the 1980s featured an ideological inclination in the direction of market deregulation and government retrenchment, one would expect a reduction in the frequency of state corporate tax increases after the mid1980s. I test this hypothesis with a period dummy that equals one after 1986, year symbolizing the last major federal tax reform in the U.S. and a reference point during the "Neoliberal" takeover. I also explore the importance of left-right political ideology in state corporate tax reforms with a dummy measuring the party affiliation of policymakers. Figure 1 summarizes the potential sources of endogeneity present in the analysis of corporate tax policy reforms.

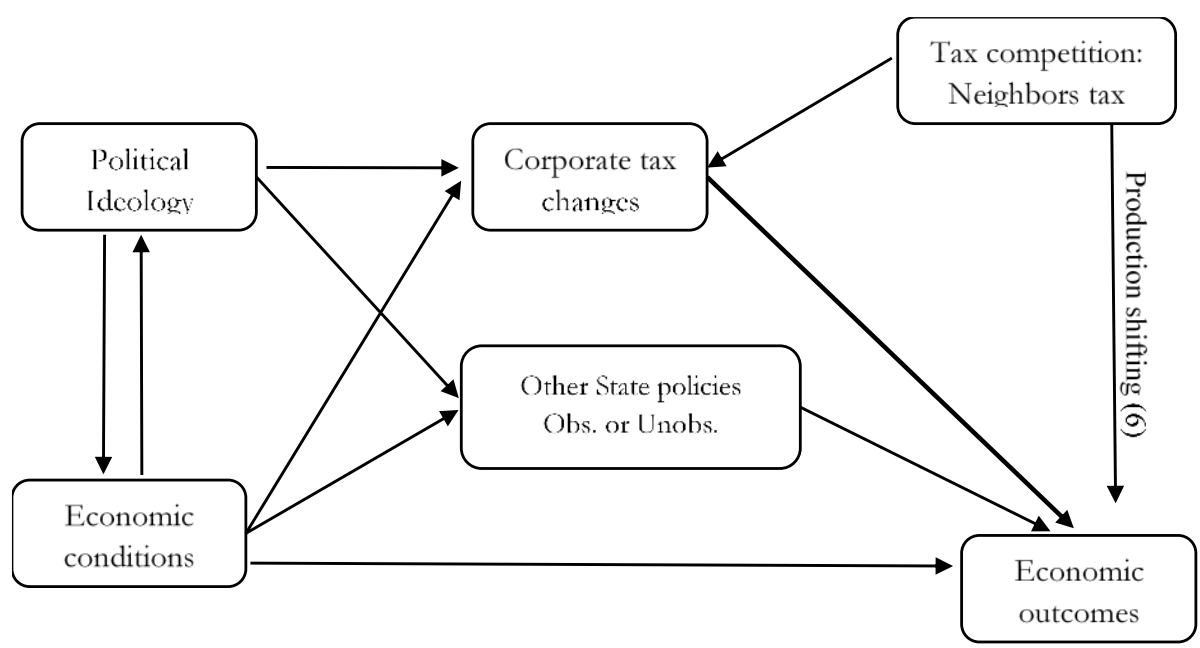

Figure 1. Potential Sources of Endogeneity in Corporate Tax Reforms 
As described on the figure, identifying the causal incidence of corporate tax reforms remains a remarkable challenge. The diagram above highlights among other things, how the relationship of interest is cofounded by unobservables that relate to both the political affiliation of policymakers and economic outcomes. These factors which are time-varying in nature (and cannot be addressed by typical fixed effects regressions) include hard-to-capture regulations, norms and directives that influence business decision-making and outcome variables of interest. But the political shade of decision makers is not exogenous and is likely determined by previous economic conditions. Therein lies the challenge of measuring these elasticities. The main goal of this paper is to explore the significance of these relationships which would cofound the channel of association that runs from corporate tax reforms to economic outcomes.

\section{Background: Structure and Trends of State Corporate Taxation in the U.S.}

On top of the federal corporate income tax rate of 21 percent(note 1), most U.S. states impose a tax on the profits of businesses operating within their jurisdiction. Of the 50 states, only five - Nevada, South Dakota, Texas, Washington and Wyoming - do not tax corporations as separate productive institutions in 2014. Texas and Washington impose a business sales tax on firms irrespective of their legal form of organization.

The tax schedule is not linear in most states(note 2), and provisions are made with regards to the deductibility of federal tax payments in some states. Also, the treatment of firms engaged in activities across several states varies widely. There is a combined reporting legislation in 23 of the 45 states with a corporate tax that requires corporations operating in multiple states to report aggregate profits for taxation. State tax liabilities are determined on the basis of an apportionment rule. This formula uses a combination of sales, property, and employment to estimate taxes due within each jurisdiction.

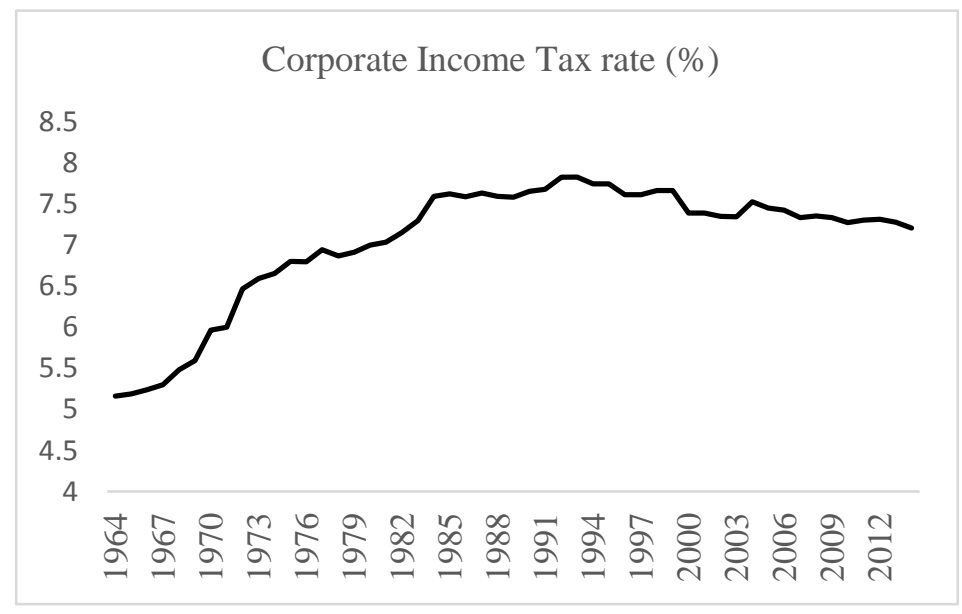

Figure 2. Average State Statutory Corporate Rates 


\section{MInstitute ${ }^{\text {Mink }}$}

Among states that tax corporate profits, there is a substantial variation in the state corporate tax rate over time. To illustrate these dynamics, I plot the average statutory and effective top marginal tax rates over time (See Figure 2). Averaged across states, statutory tax rates increased from 3.7 percent in 1960 to a high of 7.0 percent in 1993 and have since fallen to 6.5 percent in 2014, the lowest it has been since 1981. Only sept states have lower tax rates in 2014 than they did in 1964; 36 have higher tax rates.

The patterns of state corporate tax reforms over time could be broken down into two subperiods. Before the rise of economic liberalism in the early 1980s, the typical state is about twelve times more likely to feature a corporate tax increase than a decrease in any given year (See Figure 3). This disparity is also associated with substantial differences in rate changes. Prior to 1980, the regular state corporate tax cut averages 0.6 percentage point while the usual tax increase averages 1.1 percentage point. As a result, there is an upward trend in the average state corporate tax rate over the period 1964-1980 (See Figure 2). In contrast, following the two major tax legislations(note 3 ) in the 1980s, there was a reversal in the frequency of business tax hikes and reductions.

Over the period 1988-2014, there are about three state tax cuts as opposed to one tax increase on average in a given year. Relatedly, the average rate cut substantially increased (from 0.6 percent to 1.0 percent) while the average rate hike barely changed (from 1.1 percent to 1.0 percent). This combination of factors explains the moderate downward trend observed on the average corporate tax rate curve over the period 1988-2014.

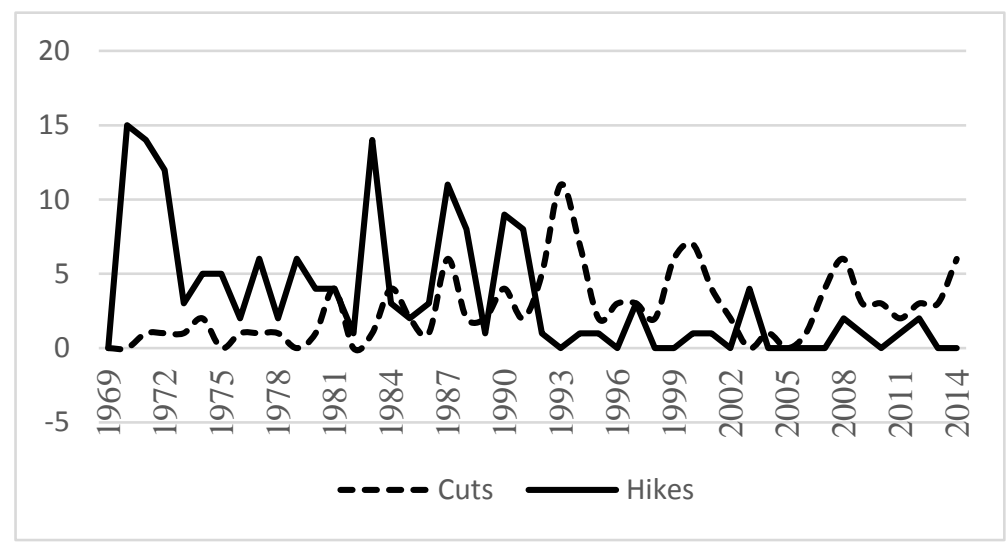

Figure 3. Number of State Corporate Tax Cuts and Hikes

The dynamics described above could be linked to several developments. First, as discussed earlier, the 1980s were marked by a series of tax reforms at the federal level. These changes were introduced along with other policies that swayed the pendulum of political ideas towards market-friendly policies and institutions. This context may have contributed to the slowdown in policymakers' incentives to raise taxes on businesses. Plus, the growing nature of tax competition between states and localities as well as the deepening of globalization that originated during this era could be considered as complementary forces driving these state policies. 


\section{Data Sources and Variables}

The subsequent analysis explores the political economy of state corporate tax reforms in the U.S. by utilizing data on state effective corporate income rates over the period 1969-2014. One recurrent theme in the empirical literature of corporate tax incidence relates to the difficulty of measuring corporate tax liabilities borne by firms. The top marginal statutory rate favored by investigators working on this topic features some limitations. It does not capture provisions such as depreciation allowances, deductibility of some costs, and rules of expensing that would lower the effective burden of the tax on corporations.

Several U.S. states provide investment tax credits and allow firms to deduct federal corporate taxes paid from state taxes owed. These incentives reduce the effective tax rate on corporations. Using information in the "Books of the States" reports, Chirinko and Wilson constructed a series of state effective corporate tax rates over the period 1964-2006. I extended the dataset to 2014 using information available on state websites and statutory corporate rates provided by the Tax Foundation. The formula used to construct this variable is described in the Appendix. Variations in this variable might result from statutory corporate rate changes but can also be inherent to developments with respect to other provisions that affect the user cost of capital. I consider both the statutory and the effective tax rates in all regressions featured in this paper(note 4).

Tax reform at the state level undergoes a process identical to the design at the federal level. Changes to the tax code usually originate from the executive branch of the government which submits a new tax legislation to both houses of the legislative branch through the budget process. The proposal would thereafter be studied by appropriate committees and submitted for voting after potential amendments. The economic literature generally assumes that policy changes reflect the median voter' preferences. However, a recent series of works drawing on public choice theory emphasize that policymakers could be motivated by other considerations ranging from self-interest to satisfying big donors.

In this paper, I adopt the traditional view of policy changes reflecting median voter choices for a few reasons. First, to the best of my knowledge, there is no organized time series of campaign financing and contributions by source for each political candidate at the state level. This information is certainly available, but it has not been compiled in a fashion that would enable its use in an empirical set-up. Second, even though the literature of public choice analysis has for long examined the agency problem involved in public policy decisions, few works empirically tested the theoretical predictions due to the lack of an extensive dataset.

To capture the political control of a state, I use a combination of dummies that measure the ideological affiliation of the party controlling the executive branch and both state houses. This information is collected online from the National Conference and State Legislature (NCSL) website. This bipartisan organization follows changes in the political landscape, policy reforms and budget trends across U.S. states over time. I assume that a state is under Republican control when both the Executive and the Legislative Houses are controlled by the Republican party. In contrast, when both institutions are dominated by Democrats, I consider the state to be under 


\section{Macrothink}

Research in Applied Economics

ISSN 1948-5433 2019, Vol. 11, No. 3

Democratic Control. The "No control" dummy refers to a situation where no party controls all institutions simultaneously.

Table 1: Summary statistics of main variables

\begin{tabular}{|c|c|c|c|c|c|c|}
\hline Variable & Description & & Mean & S. D. & Min & Max \\
\hline davg & $\begin{array}{l}\text { Diff. with tax } \\
\text { Avg. of neighbors }\end{array}$ & $\begin{array}{l}\text { overall } \\
\text { between } \\
\text { within }\end{array}$ & -0.001 & $\begin{array}{l}0.028 \\
0.026 \\
0.012\end{array}$ & -0.078 & 0.072 \\
\hline cut & Corporate tax Cut dummy & $\begin{array}{l}\text { overall } \\
\text { between } \\
\text { within }\end{array}$ & 0.056 & $\begin{array}{l}0.230 \\
0.059 \\
0.222\end{array}$ & 0.000 & 1.000 \\
\hline hike & Corporate tax Hike dummy & $\begin{array}{l}\text { overall } \\
\text { between } \\
\text { within }\end{array}$ & 0.072 & $\begin{array}{l}0.258 \\
0.046 \\
0.254\end{array}$ & 0.000 & 1.000 \\
\hline repcon & Republican control dummy & $\begin{array}{l}\text { overall } \\
\text { between } \\
\text { within }\end{array}$ & 0.182 & $\begin{array}{l}0.386 \\
0.192 \\
0.335\end{array}$ & 0.000 & 1.000 \\
\hline demcon & Democratic control dummy & $\begin{array}{l}\text { overall } \\
\text { between } \\
\text { within }\end{array}$ & 0.306 & $\begin{array}{l}0.461 \\
0.233 \\
0.399\end{array}$ & 0.000 & 1.000 \\
\hline ggsp & Growth of output & $\begin{array}{l}\text { overall } \\
\text { between } \\
\text { within }\end{array}$ & 0.029 & $\begin{array}{l}0.037 \\
0.008 \\
0.036\end{array}$ & -0.168 & 0.305 \\
\hline debt_gsp & Debt to output ratio & $\begin{array}{l}\text { overall } \\
\text { between } \\
\text { within }\end{array}$ & 0.643 & $\begin{array}{l}0.387 \\
0.338 \\
0.195\end{array}$ & 0.030 & 2.276 \\
\hline budef & Dummy for budget deficit & $\begin{array}{l}\text { overall } \\
\text { between } \\
\text { within }\end{array}$ & 0.177 & $\begin{array}{l}0.382 \\
0.075 \\
0.374\end{array}$ & 0.000 & 1.000 \\
\hline
\end{tabular}




\section{Macrothink}

The Bureau of Economic Analysis provides annual statistics on employment and output by industry for every U.S. state going back to 1969. The Bureau also releases aggregates of this information for the eight economic subdivisions commonly used for regional analysis. I measure the growth of employment and output (Gross State Product) as relative annual changes at the end of the year. Statistics on state unemployment rates are produced by the Bureau of Labor Statistics (BLS) through the Local Area Unemployment Statistics (LAUS) program going back to 1976. This data is derived from the Current Population Survey (CPS) which follows labor market participation trends across households monthly. I use these variables to control for business cycle fluctuations at the state or regional level.

Finally, I also explore the extent to which a state's fiscal position affects corporate tax policies. Even in the presence of a Balanced Budget Requirement (BBR), a state can still run deficits over a sustained period especially with ex-ante BBR rules. The information on state government debt, revenues, expenditures and fiscal position is collected by the Census Bureau going back to 1992 through the state and local government finance report. The dataset has been extended all the way back to 1967 by Pierson K., Hand M., and Thompson F. (2015) of the University of Willamette through the government finance database. Using this information, I constructed a "deficit" dummy that equals one if a state runs a fiscal deficit in any given year and control for a state's debt to output ratio in some specifications. I describe the summary statistics of the variables used in all regressions in Table 1.

\section{Estimation}

The empirical work carried out in this paper intends to identify the factors associated with a state's decision to change its business tax code. I am not seeking to uncover the causal relationships between the variables of interest and a state's decision to amend its corporate tax code. The ideal experiment that will enable the measurement of such causal effects, would require randomly assigning exogenous business cycles or public fiscal position to a state or alternative corporate tax schemes to its neighbors, and observe how otherwise similar states react to these developments. This is hard to implement, and quasi-experimental settings are cofounded by time-varying unobservables. The main objective of this analysis is to identify the set of variables that predict corporate tax reforms at the state level, hence exposing the main identification challenges that should be a matter of concern to the empirical literature.

I estimate a model with a panel of 48 U.S. states over the period 1969-2014. I excluded Hawaii and Alaska which are not located on the mainland territory and do not face the same degree of tax competition from contiguous neighbors. The design of this paper presents a variety of empirical issues including spatial correlation in tax policy but also serial correlation in tax changes over time at the state level(note 5). I address these considerations by clustering the error terms at the state and regional level. In most specifications, I included time-invariant fixed effects to capture unobserved differences in the preference for policy reforms in a state. I also included a dummy that equals one after the year 1986, which marks the last major federal corporate tax reform in the U.S. I estimate the following specifications: 


$$
\begin{gathered}
\Delta \tau_{i t}=\alpha_{i}+\beta_{1} \mathrm{X}_{i t-1}+\theta_{11} \mathrm{~d}_{1986}+\mathrm{u}_{i t} \\
1_{\left\{\Delta \tau_{i t}<0\right\}}=\alpha_{i}+\beta_{2} \mathrm{X}_{i t-1}+\theta_{21} \mathrm{~d}_{1986}+\mathrm{u}_{i t} \\
1_{\left\{\Delta \tau_{i t}>0\right\}}=\alpha_{i}+\beta_{3} \mathrm{X}_{i t-1}+\theta_{31} \mathrm{~d}_{1986}+\mathrm{u}_{i t}
\end{gathered}
$$

$\Delta \tau_{\text {it }}$ refers to the change of corporate statutory or effective tax change in state $i$ during year $t$ while $\mathrm{X}_{\mathrm{it}-1}$ represents a set of covariates measured at $i$ and $t-1$ and likely to influence state corporate tax policies. This set includes the following variables: (i) debt to output ratio, (ii) the difference between a state's corporate rate and the average of its contiguous neighbors, (iii) the growth of output, (iv) a dummy for the presence of a fiscal deficit and (v) dummies for the party affiliation of the political control of a state's institutions. $\alpha_{i}$ represents state time-invariant fixed effects while $\theta_{\mathrm{k} 1}$ in equation $k$ captures the post-TRA effect on state corporate tax reforms. Notice that this parameter is not identified when including year effects.

The control variables are lagged to account for the general design of tax policy reforms, which are usually announced with a one-year lead period. Plus, there is a strong contemporaneous association between corporate tax rates and several of the control variables such as budget deficit, debt or output growth; and this relationship is not of primary interest in this analysis. I am also aware of the consideration that these control variables are endogenous, nonetheless, the lagged controls are predetermined with respect to state corporate tax reforms.

Specification (1) explores the determinants of the magnitude of a state corporate tax change. In contrast, specifications (2) and (3) investigate the factors driving incentives to cut or increase the rate in the first place. These last two specifications are estimated using a Linear Probability Model (LPM) with robust standard errors. Using this approach, I intend to distinguish between a rather "intensive margin" associated with the magnitude of state rate changes from a more "extensive margin" relative to the decision to cut or increase the corporate rate.

\section{Empirical findings}

Table 2 presents the details of the political economy of a state's statutory and effective corporate tax changes. Panel (1) describes the association between the control variables and the magnitude of a state's corporate tax change. Panels (2) and (3) distinguish between incentives driving corporate rate cuts and increases. The results exposed in the table suggest that tax competition with neighbors, economic cycles and Republican control of a state correlate with corporate tax reforms. In contrast, long-term debt and budgetary constraints do not seem to significantly influence these policy incentives. I also notice a shift in the pattern of corporate rate changes after the federal Tax Reform Act of 1986. 


\section{Al Macrothink}

Research in Applied Economics

ISSN 1948-5433 2019, Vol. 11, No. 3

Table 2. Effects of Domestic Political Economy on Statutory and Effective Corporate Tax Reforms

\begin{tabular}{|c|c|c|c|c|c|c|}
\hline \multirow{2}{*}{$\begin{array}{l}\text { Dependent variable } \\
\text { Specification }\end{array}$} & \multicolumn{3}{|c|}{ Effective rate ${ }^{(a)}$} & \multicolumn{3}{|c|}{ Statutory rate ${ }^{(a)}$} \\
\hline & (1) & (2) & (3) & (1) & (2) & (3) \\
\hline & Change & Cut & Hike & Change & Cut & Hike \\
\hline \multicolumn{7}{|l|}{ Tax competition } \\
\hline \multicolumn{7}{|l|}{${ }^{(a)}$ Diff. with avg. rate of } \\
\hline \multirow[t]{2}{*}{ contiguous states $_{t-1}$} & $-0.047 * * *$ & $1.467 *$ & $-2.575 * * *$ & $-0.049 * * *$ & $1.387 *$ & $-2.083 * * *$ \\
\hline & $(0.016)$ & $(0.912)$ & $(0.946)$ & $(0.017)$ & $(0.848)$ & $(0.845)$ \\
\hline \multicolumn{7}{|l|}{ Domestic economy } \\
\hline \multirow[t]{2}{*}{${ }^{(a)}$ Growth output $t_{t-1}$} & $-0.009 * * *$ & -0.117 & $-0.724 * * *$ & $-0.006 * * *$ & -0.132 & $-0.391 * * *$ \\
\hline & $(0.002)$ & $(0.144)$ & $(0.175)$ & $(0.002)$ & $(0.143)$ & $(0.148)$ \\
\hline \multicolumn{7}{|l|}{ Political Control } \\
\hline \multirow[t]{2}{*}{ Republican Control $_{t-1}$} & $-0.007 * * *$ & 0.013 & $-0.048 * * *$ & $0.007 * * *$ & $0.052 * *$ & $-0.029 * *$ \\
\hline & $(0.001)$ & $(0.023)$ & $(0.014)$ & $(0.001)$ & $(0.026)$ & $(0.013)$ \\
\hline \multirow[t]{2}{*}{ Democratic Control $_{t-1}$} & 0.000 & -0.001 & 0.014 & 0.000 & 0.017 & 0.006 \\
\hline & $(0.001)$ & $(0.019)$ & $(0.015)$ & $(0.002)$ & $(0.014)$ & $(0.016)$ \\
\hline \multicolumn{7}{|l|}{ Budgetary pressures } \\
\hline \multirow[t]{2}{*}{ Budget Deficit ${ }_{t-1}$} & -0.001 & -0.011 & $-0.030 * *$ & -0.000 & -0.016 & -0.005 \\
\hline & $(0.001)$ & $(0.013)$ & $(0.013)$ & $(0.001)$ & $(0.014)$ & $(0.012)$ \\
\hline \multirow[t]{2}{*}{ Debt to output ratio $t-1$} & $-0.001 *$ & -0.036 & -0.009 & -0.005 & 0.020 & -0.041 \\
\hline & $(0.000)$ & $(0.046)$ & $(0.024)$ & $(0.004)$ & $(0.037)$ & $(0.019)$ \\
\hline \multirow[t]{2}{*}{ Post-1986 dummy } & $-0.006^{* * * *}$ & $0.033 * *$ & $-0.036 * * *$ & $-0.006 * * *$ & $0.034 * *$ & $0.038 * * *$ \\
\hline & $(0.001)$ & $(0.017)$ & $(0.001)$ & $(0.001)$ & $(0.017)$ & $(0.012)$ \\
\hline \multirow[t]{2}{*}{ Constant } & $0.001 * * *$ & 0.008 & $0.116 * * *$ & $0.001 * * *$ & 0.002 & $0.112 * * *$ \\
\hline & $(0.000)$ & $(0.027)$ & $(0.021)$ & $(0.000)$ & $(0.026)$ & $(0.018)$ \\
\hline Observations & 1824 & 1824 & 1824 & 1824 & 1824 & 1824 \\
\hline State fixed effects & Yes & Yes & Yes & Yes & Yes & Yes \\
\hline Region Business Cycle & No & No & No & No & No & No \\
\hline Year fixed effects & No & No & No & No & No & No \\
\hline R-squared & 0.05 & 0.03 & 0.05 & 0.04 & 0.02 & 0.04 \\
\hline
\end{tabular}

Each model is estimated by OLS with a panel of 48 U.S. states over the period 1969-2014.

All standard errors are robust and clustered at the state level. ${ }^{(a)}$ Effective and statutory tax changes are measured in units (5\% is equivalent to 0.05$)$. ${ }^{*}$ significant at $10 \%$; ${ }^{* *}$ significant at $5 \%$; ${ }^{* * *}$ significant at $1 \%$

\subsection{The Role of Tax Competition}

It appears that a state is more likely to cut its corporate rate when it is above the average of its closest competitors but is more likely to increase it when it is below this same average. A one percent point above the average of a state's contiguous neighbors' rates increases the probability of a corporate effective rate cut by 1.46 percentage point and reduces the probability 
of a corporate rate increase by 2.52 percentage points. Alternatively, a one percent point above neighbors' rate associates with an average corporate change of -0.04 percentage points.

The symmetrical interpretation of this finding implies that the standard error of this estimate might be biased if all states react to the same average target. I address this consideration by clustering the error term at the region-year level. These patterns support the hypothesis of a positive reaction curve and some degree of convergence towards a regional average, though the reaction to neighbors' policies might take a while to manifest. The literature on tax competition has generally defended that states positively react to the tax rates of competitors when designing domestic tax policy (Altshuler \& Goodspeed, 2003) in a game-theoretic setup.

This consensus has been recently challenged by a series of works (Chirinko \& Wilson, 2017) which emphasize that the slope of the reaction curve could be negative or uncertain in the presence of heterogeneous preferences for public goods across regions. In equilibrium, voters would choose a combination of tax rates and public goods to maximize welfare. Corporate tax hikes in neighboring states will increase domestic income and might induce a business tax cut if there is a weak preference for public goods relative to private goods. The results in Table 2 support the traditional view of a positive reaction function, with states looking to emulate neighbors to remain competitive. Though the response to neighbors' rate changes could take a while to set in, the average rate of neighbors in the year preceding a reform is quite informative. This variable is pre-determined at the moment of a tax reform and summarizes previous corporate tax policies of a state's neighbors.

\subsection{The Importance of Ideology and Political Control}

Political ideology not only reflects voters' preferences but also affects policy developments. Right to center affiliation generally correlates with market-friendly and government retrenchment ideas. This usually translates into Republican elected officials supporting cuts to business taxation, while Democrats are more likely to undertake tax increases to finance social obligations. The results in Table 2 confirm this prediction, suggesting that a Republican control of a state's institutions is more likely to induce a statutory corporate tax cut and less likely to result in a business tax hike.

Specifically, when both houses and the government of a state are under Republican control, the probability of a corporate tax cut increases by 5.20 percentage points. In contrast, under the same circumstances, the probability of a corporate rate hike shrinks by 2.92 percentage points. These effects are measured relative to the "No control" scenario when neither party controls all political institutions. This finding is interesting if one considers the fact it has been established after controlling for economic trends.

Voters' preferences for one shade of the political spectrum is often driven by economic conditions but also influences the taxation of capital. Alternatively, political ideology might associate with several other policies (such as investment tax credits, personal income tax, and other supply-side incentives) that in turn shape economic outcomes. The results presented in Table 2 suggest that political ideas determine corporate tax policies even when states are 
exposed to similar economic conditions. All else equal, a Republican control of institutions predicts a higher likelihood of a business tax cut and a lower probability of a tax increase. In contrast, democratic control does not seem to significantly affect corporate tax policies.

\subsection{The Influence of the "Reagan Revolution"}

The neoliberal order that emerged in the 1980s resulted in the adoption of several marketfriendly policies. The theoretical justification for this political revolution can be traced back to the Laffer Curve, which suggests that tax cuts might translate into higher tax collections under a set of circumstances. The landmark policy that embodies this intellectual school of thought took effect through the Tax Reform Act (TRA) of 1986 that considerably reduced tax rates on corporate and personal income. The reform was followed by a series of market deregulations set to limit the role of the public sector in the economy. This philosophical takeover seems to have influenced the frequency and direction of state corporate rate changes.

I notice that after the federal tax reform of 1986, the probability of a state corporate tax cut increases by 3.32 percentage points while the likelihood of a state corporate rate hike decreases by 3.60 percentage points. Plus, the average tax change in a state is 0.62 percentage point lower than it was prior to the reform. These results are robust to falsification tests that consider alternative structural breakpoints. The change appears to have begun around the aftermath of the TRA and remains significant regardless of the party affiliation of state policymakers.

A few factors can explain this development. First, the interdependency between states and the federal government particularly on corporate taxation sets-up a strategic interaction with respect to tax rates. Many states allow corporations to deduct federal corporate taxes paid from their state liabilities. This implies that a rate change at the federal level will alter state corporate tax revenues if nothing is done. Second, the intensification of neoliberal policies at the national level probably affected federal grants and other resources available to states, which might in turn, contribute to the adoption of business-friendly policies to promote growth and make up for the lost revenue. Third and importantly, the wave of market-oriented reforms that marked the Reagan administration may have carried through local politics and influenced voters and policymakers' preferences with respect to the size of government in the economy (Campbell, 1998).

\subsection{The Impacts of Economic Conditions and Regional Heterogeneity}

A major driver of state corporate tax reforms originates from pre-existing economic conditions. During regional and local recessions, states are likely to provide tax breaks and several incentives to offset the adverse effects of contraction on employment. Corporate tax rates are part of the set of instruments that can be manipulated to spur economic growth during downturns. Alternatively, states might increase corporate tax rates or borrow to finance the uptake in social obligations (increase in unemployment insurance for example) during recessions. Corporate tax reforms can also be motivated by fiscal constraints and public debt. States could increase tax rates to finance budget deficits or pay off the public debt. 
Table 3. Results with Regional Business Cycle (deviation of regional employment from average)

\begin{tabular}{|c|c|c|c|c|c|c|}
\hline \multirow{2}{*}{$\begin{array}{l}\text { Dependent variable } \\
\text { Specification }\end{array}$} & \multicolumn{3}{|c|}{ Effective rate $e^{(a)}$} & \multicolumn{3}{|c|}{ Statutory rate ${ }^{(a)}$} \\
\hline & (1) & (2) & (3) & (1) & (2) & (3) \\
\hline & Change & Cut & Hike & Change & Cut & Hike \\
\hline \multicolumn{7}{|l|}{ Tax competition } \\
\hline \multicolumn{7}{|l|}{${ }^{(a)}$ Diff. with avg. rate of } \\
\hline \multirow[t]{2}{*}{ contiguous states $_{t-1}$} & $-0.007 * * *$ & $0.793 * *$ & -0.073 & $-0.008 * * *$ & $0.782 * *$ & -0.002 \\
\hline & $(0.002)$ & $(0.400)$ & $(0.219)$ & $(0.003)$ & $(0.351)$ & $(0.172)$ \\
\hline \multicolumn{7}{|l|}{ Domestic economy } \\
\hline \multirow[t]{2}{*}{${ }^{(a)}$ Growth output ${ }_{t-1}$} & $-0.008 * * *$ & 0.132 & $-0.703 * * *$ & 0.005 & 0.128 & $-0.442 * * *$ \\
\hline & $(0.002)$ & $(0.196)$ & $(0.183)$ & $(0.003)$ & $(0.200)$ & $(0.173)$ \\
\hline \multicolumn{7}{|l|}{ Political Control } \\
\hline \multirow[t]{2}{*}{ Republican Control $t_{t-1}$} & $-0.004 * * *$ & 0.010 & $-0.030 * * *$ & $0.005 * * *$ & $0.049 * *$ & $-0.013 *$ \\
\hline & $(0.001)$ & $(0.023)$ & $(0.008)$ & $(0.001)$ & $(0.025)$ & $(0.009)$ \\
\hline \multirow[t]{2}{*}{ Democratic Control $t-1$} & 0.000 & -0.006 & 0.013 & 0.000 & 0.015 & 0.006 \\
\hline & $(0.001)$ & $(0.019)$ & $(0.014)$ & $(0.000)$ & $(0.014)$ & $(0.014)$ \\
\hline \multicolumn{7}{|l|}{ Budgetary pressures } \\
\hline \multirow[t]{2}{*}{ Budget Deficit $t_{t-1}$} & -0.000 & -0.013 & $-0.031 * * *$ & -0.000 & -0.016 & -0.001 \\
\hline & $(0.000)$ & $(0.013)$ & $(0.013)$ & $(0.001)$ & $(0.014)$ & $(0.012)$ \\
\hline \multirow[t]{2}{*}{ Debt to output ratio ${ }_{t-1}$} & -0.000 & 0.037 & -0.006 & $-0.000^{*}$ & 0.020 & -0.001 \\
\hline & $(0.000)$ & $(0.026)$ & $(0.015)$ & $(0.000)$ & $(0.037)$ & $(0.012)$ \\
\hline \multirow[t]{2}{*}{ Post-1986 dummy } & $-0.007 * * *$ & $0.033 * *$ & $-0.043 * * *$ & $-0.008 * * *$ & $0.031 * *$ & $-0.045 * * *$ \\
\hline & $(0.001)$ & $(0.017)$ & $(0.013)$ & $(0.001)$ & $(0.016)$ & $(0.013)$ \\
\hline \multirow[t]{2}{*}{ Constant } & $0.001 * * *$ & 0.015 & 0.122 & $0.001 * * *$ & -0.003 & $0.086 * * *$ \\
\hline & $(0.000)$ & $(0.024)$ & $(0.019)$ & $(0.000)$ & $(0.026)$ & $(0.017)$ \\
\hline Observations & 1824 & 1824 & 1824 & 1824 & 1824 & 1824 \\
\hline State fixed effects & Yes & Yes & Yes & Yes & Yes & Yes \\
\hline Regional Business Cycle & Yes & Yes & Yes & Yes & Yes & Yes \\
\hline Year fixed effects & No & No & No & No & No & No \\
\hline R-squared & 0.03 & 0.02 & 0.03 & 0.03 & 0.02 & 0.02 \\
\hline
\end{tabular}

Each model is estimated by OLS with a panel of 48 U.S. states over the period 1969-2014.

All standard errors are robust and clustered at the state level. Regional Business Cycle is proxied by deviation of regional employment from average. ${ }^{(a)}$ Effective and statutory tax changes are measured in units $(5 \%$ is equivalent to 0.05$).{ }^{*}$ significant at $10 \% ;{ }^{* *}$ significant at $5 \%$; ${ }^{* *}$ significant at $1 \%$

The results described in Table 2 indicate that states are more likely to undertake corporate tax changes when economic growth is below average. In contrast, running a budget deficit or high levels of public debt does not seem to significantly affect the probability of a corporate tax change. Specifically, statutory corporate tax increase and decrease occur respectively when 
output growth is 0.39 percentage point and 0.13 percentage point below average, though the latter estimate is not statistically significant. I have also explored an alternative specification which controls for the average growth (Table 3) of output over a three-year period leading to the corporate tax change and did not notice any significant association between pre-existing economic conditions and the propensity to cut or increase corporate tax rates. The negative correlation between economic growth and increases in corporate tax rates is counterintuitive but offer some support to the hypothesis that states raise additional corporate tax revenue to finance expenditures during downturns. The empirical evidence on the political economy of tax reforms at the country-level (Swank and Steinmo, 2002) favors the opposite conclusion (i.e.) a positive correlation between growth and the direction of corporate tax changes.

I also document a heterogeneity of corporate tax reforms across economic regions. As evidenced in Table 4, states in "New England" and the "Great Lakes" are more likely to revert to statutory corporate rate increases than those in the West (Far West, Rocky Mountain, and Southwest) and the "Southeast". This result holds with the inclusion of the set of control variables used above as well as regional business cycle trends, suggesting that when exposed to similar circumstances, states in certain regions are more likely to increase their tax rates than others. I do not notice this regional heterogeneity with regards to corporate tax cuts. This finding likely reflects unobserved heterogeneity related to the structure of economic activities in a region or the strength of regional integration.

Table 4. Results with Regional Heterogeneity

\begin{tabular}{lllllll}
\hline Dependent variable & \multicolumn{5}{c}{ Effective rate $^{(a)}$} & \multicolumn{3}{c}{ Statutory rate $^{(a)}$} \\
Specification & $(1)$ & $(2)$ & $(3)$ & $(1)$ & $(2)$ & $(3)$ \\
& Change & Cut & Hike & Change & Cut & Hike \\
Region (excluded New & & & & & & \\
England) & & & & & & \\
Mideast & & & & & & \\
& -0.0004 & -0.021 & $-0.039^{*}$ & -0.0004 & -0.029 & $-0.057^{* * *}$ \\
Great Lakes & $(0.0003)$ & $(0.035)$ & $(0.024)$ & $(0.0003)$ & $(0.028)$ & $(0.024)$ \\
& -0.0006 & 0.024 & -0.024 & -0.0006 & 0.017 & -0.024 \\
Plains & $(0.0005)$ & $(0.037)$ & $(0.026)$ & $(0.0005)$ & $(0.037)$ & $(0.024)$ \\
& -0.0002 & -0.023 & -0.003 & -0.0004 & -0.033 & $-0.046^{* *}$ \\
Southeast & $(0.0003)$ & $(0.036)$ & $(0.029)$ & $(0.0003)$ & $(0.036)$ & $(0.024)$ \\
\multirow{5}{*}{ Southwest } & -0.0004 & -0.002 & $-0.036^{*}$ & $-0.0005^{* *}$ & -0.031 & $-0.064^{* * *}$ \\
& $(0.0002)$ & $(0.038)$ & $(0.024)$ & $(0.0002)$ & $(0.040)$ & $(0.020)$ \\
Rocky Mountain & -0.0004 & -0.049 & -0.026 & -0.0004 & -0.035 & $-0.054^{* * *}$ \\
& $(0.0004)$ & $(0.036)$ & $(0.024)$ & $(0.0004)$ & $(0.037)$ & $(0.025)$ \\
Far West & -0.0002 & -0.037 & -0.036 & -0.0001 & -0.049 & $-0.048^{* *}$ \\
& $(0.0003)$ & $(0.039)$ & $(0.027)$ & $(0.0003)$ & $(0.042)$ & $(0.024)$ \\
& -0.0005 & -0.034 & $-0.058^{* *}$ & -0.0005 & -0.031 & $-0.061^{* * *}$ \\
& $(0.0003)$ & $(0.030)$ & $(0.027)$ & $(0.0004)$ & $(0.030)$ & $(0.023)$ \\
\hline
\end{tabular}




\begin{tabular}{lllllll} 
Constant & $-0.0016 * * *$ & 0.029 & $0.156^{* * *}$ & $0.0018 * * *$ & 0.024 & $0.165^{* * *}$ \\
& $(0.0004)$ & $(0.045)$ & $(0.035)$ & $(0.0004)$ & $(0.045)$ & $(0.031)$ \\
Observations & 1824 & 1824 & 1824 & 1824 & 1824 & 1824 \\
State fixed effects & No & No & No & No & No & No \\
Regional Business Cycle & Yes & Yes & Yes & Yes & Yes & Yes \\
Region fixed effects & Yes & Yes & Yes & Yes & Yes & Yes \\
All other controls & & & & & & \\
included & Yes & Yes & Yes & Yes & Yes & Yes \\
R-squared & 0.02 & 0.03 & 0.03 & 0.02 & 0.03 & 0.03 \\
\hline
\end{tabular}

Each model is estimated by OLS with a panel of 48 U.S. states over the period 1969-2014.

All standard errors are robust and clustered at the state level. Regional Business Cycle is proxied by deviation of regional employment growth from average in a given year. ${ }^{(a)}$ Effective and statutory tax changes are measured in units (5\% is equivalent to 0.05$).{ }^{*}$ significant at $10 \%$; ${ }^{* *}$ significant at $5 \%$; ${ }^{* * *}$ significant at $1 \%$

\section{Implications for the Empirical Literature}

The political economy of state corporate tax reforms matters for the empirical literature which is increasingly concerned with the identification of corporate tax elasticities. The dominant strategy that exploits exogenous variations in corporate tax rates to capture these causal elasticities, though flawed (Kahn and Whited 2017), remains valuable. Figure 1.4 presents a schematic description of the complexities of corporate tax reforms. The causal effect of interest that runs from tax reforms to economic outcomes could be identified with ad hoc empirical approaches.

As illustrated on the graph, there are several backdoor channels that correlate with both business tax reforms and economic outcomes. Some of those are unobserved and several others are just hard to measure. An empirical investigation of the short-run corporate tax incidence would consider all associations between rate changes and economic outcomes. The figure below describes the evidence exposed in this paper. It also suggests that a reliable account of the elasticity of interest - relationship (1) - would have to block all other cofounding channels.

For instance, some empirical works on this topic have used the average rate of neighboring states/countries as an instrument for domestic corporate tax policies (Lee and Gordon, 2004). This method is flawed as evidenced by relationship (6) on the graph. Though neighbors' rates influence domestic corporate tax policies, they also affect domestic production, employment, and wages through activity shifting. Businesses in neighboring states would likely react to tax changes by moving part of their production into the domestic economy. This clearly violates the exclusion condition. Other papers have compared contiguous counties around state corporate rate changes (Ljungqvist and Smolyansky, 2014), which might be effective if appropriately designed to block all sources of endogeneity. 


\section{Macrothink}

Most empirical studies of the corporate tax incidence do not consider the possibility of tax competition (Hassett and Mathur, 2006; Hassett et al., 1996) and the implications this bears on the treatment of standard errors. When states (or countries) react to corporate tax policy developments in neighboring economies, one classic assumption in panel data regression analysis $-\mathrm{E}\left(\varepsilon_{\mathrm{it}} \varepsilon_{\mathrm{js}}\right)=0 \quad$ - will not hold true for a pair of contiguous jurisdictions $(i, j)$ over two consecutive years $(t, s)$. This suggests that the standard errors should be adjusted for spatial correlation using traditional GLS methods.

I also argue in this paper that an effective identification strategy is one that blocks all backdoors especially those that are unobserved or hard to capture such as the effects of neighbors' policies on domestic economic outcomes. Instruments like the average rate of contiguous states/countries are only effective when supplemented with additional controls which shut down channels like relationship (6). Variables such as distance from neighbors or the existence of regional trade agreements could mediate incentives to shift activity across the border relationship (6) -.

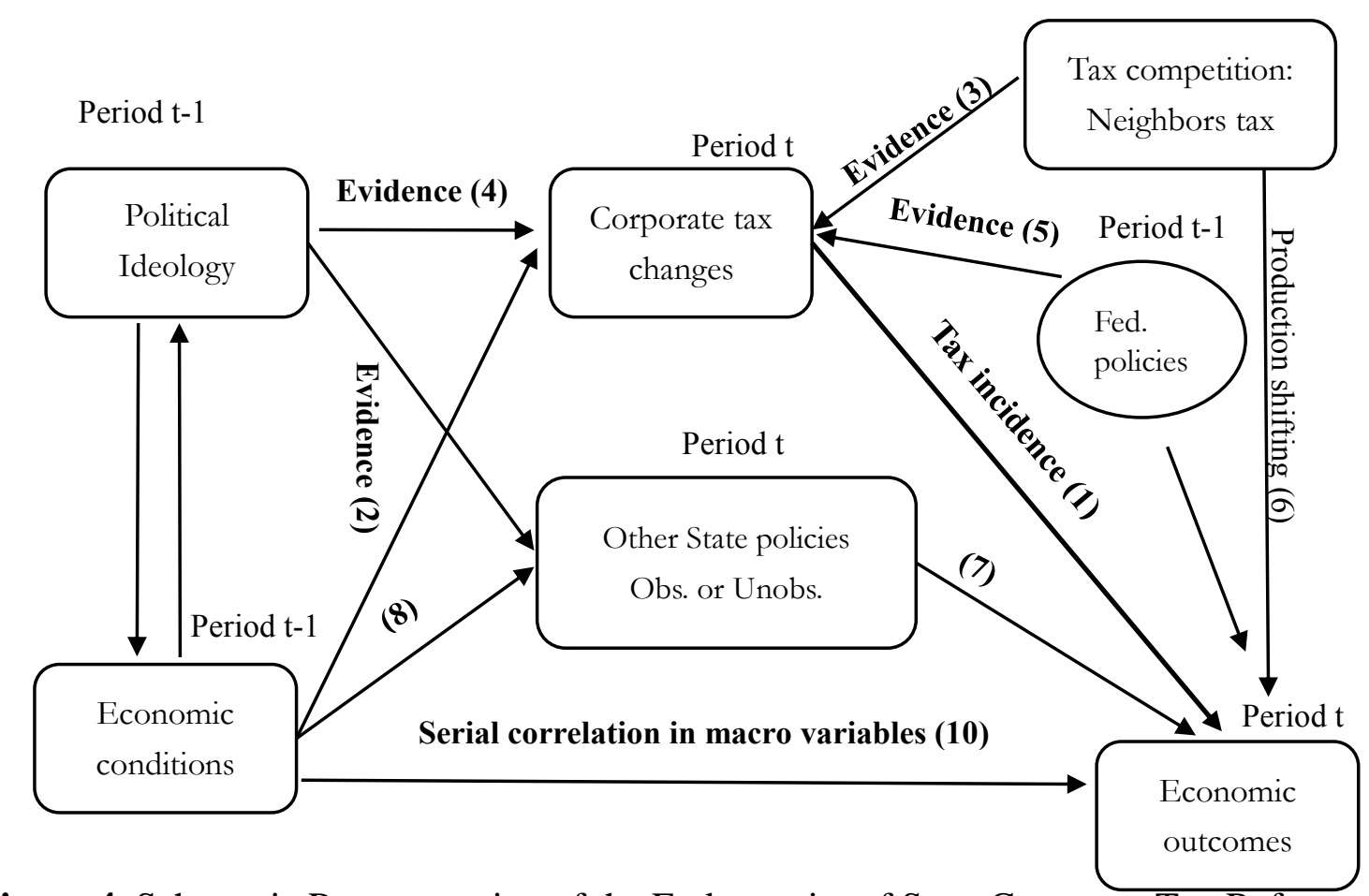

Figure 4. Schematic Representation of the Endogeneity of State Corporate Tax Reforms

\section{Conclusion}

Corporate tax policy is the subject of numerous controversies in political circles, as evidenced by the ongoing debate on the opportunity of the "Tax Cuts and Jobs Act" of 2017. Unfortunately, the empirical literature remains unsettled on the magnitude of corporate tax effects on the economy. Part of this uncertainty is methodological and relates to the difficulty of designing an appropriate identification strategy. This limitation cannot be addressed without clearly understanding the motivations (the political economy) of corporate tax reforms. I argue in this paper that U.S. state corporate tax reforms are essentially driven by tax competition, 
left-right political ideology and corporate policy developments at the federal level.

Using a unique historical record of state effective corporate tax rates over the period 19692014, I observe that state corporate tax cuts and increases are associated with tax rates in neighboring states. First, a one percent rate point above the average of a state's contiguous neighbors' rates increases the probability of a corporate effective rate cut by 1.46 percentage point and reduces the probability of a corporate rate increase by 2.52 percentage points. Second, Republican control of a state's political institutions increases the probability of a corporate tax cut by 5.20 percentage points and shrinks the probability of a corporate rate increase by 2.92 percentage points. Third, in the aftermath of the federal tax reform (TRA) of 1986, the probability of a state corporate tax cut increased by 3.32 percentage points while the likelihood of a state corporate rate hike decreased by 3.6 percentage points.

In contrast, the presence of a budget deficit and long-term debt do not predict state corporate tax changes. This finding differs from Swank and Steinmo (2002) who observed that budgetary pressures and debt are associated with corporate rate increases across countries. Differences in the ability to borrow on financial markets could offer a plausible explanation to this constrast. U.S. states are more limited in their ability to resort to financial markets to raise revenue compared to the federal government and many other governments around the world. As a result, public debt is generally modest at the state level and policymakers do not usually have to offset a recurrent negative fiscal position or high public debts through changes in tax rates. Plus, several U.S. states have an ex-post Balanced Budget Requirement (BBR) rule which constraints the propensity of sustaining fiscal deficits over a long time period.

Plus, the results described here have implications for the empirical literature, specifically regarding identification strategies. Empirical studies on the incidence of corporate taxation should address the presence of time varying unobservables along with spatial correlation due to tax competition. Traditional panel studies that observe countries (Vartia, 2008, Felix, 2007) or states (Carroll, 2009) might be limited because they do not control for heterogeneous developments in economic outcomes across regions. This heterogeneity could stem from political ideology which also influences policy changes. Other papers exploit national tax reforms and observe panels of firms (Hassett and Hubbard, 1996; Hassett and Mathur, 2010) around these presumably exogenous policies. The main challenge, in this case, is to account for other policies that affect the control units.

A few empirical works on this topic have used the average rate of neighboring states/countries as an instrument for domestic corporate tax policies (Lee and Gordon, 2004). This method is flawed as evidenced by relationship (6) on figure 4. Though neighbors' rates influence domestic corporate tax policies, they also affect domestic production, employment, and wages through activity shifting. Businesses in neighboring states would likely react to tax changes by moving part of their production into the domestic economy. This clearly violates the exclusion condition.

Most empirical studies of the state corporate tax incidence do not consider the possibility of tax competition (See for instance Hassett et al., 1996; Carroll, 2010) and the implications this would bear on the treatment of standard errors. When states (or countries) react to corporate 
tax policies in neighboring economies, the classic assumption of panel regression analysis $\mathrm{E}\left(\varepsilon_{\mathrm{it}} \varepsilon_{\mathrm{j} s}\right)=0$ - will not hold true for a pair of contiguous jurisdictions $(\mathrm{i}, \mathrm{j})$ over two consecutive years $(\mathrm{t}, \mathrm{s})$. This suggests that the standard errors should be adjusted for spatial correlation using traditional GLS methods.

This paper recommends using identification strategies that block all backdoors especially those that are unobserved or hard to capture. Instruments like the average rate of contiguous states/countries are only effective when supplemented with additional controls which shut down the possibility of activity shifting. Variables such as distance from neighbors or the existence of regional trade agreements could mediate such incentives at the firm level.

\section{References}

Altshuler \& Goodspeed (2002). Follow the Leader? Evidence on European and US Tax Competition. Public Finance Review, 46(2), 357-374. https://doi.org/10.1177/1091142114527781

Auerbach Alan J. (2006). Who Bears the Corporate Tax? A Review of What We Know. In James M. Poterba (Ed.), Tax Policy and the Economy, Volume 20. Cambridge, MA: MIT Press. https://doi.org/10.1086/tpe.20.20061903

Bertrand, Duflo \& Sendhil Mullainathan. (2002). How much should we trust Differences-indifferences estimates? MIT Working Paper No 01-34. https://doi.org/10.2139/ssrn.288970.

Bird R. M. (2012). Tax reform in Latin America : a review of some recent experiences. Latin American Research Review, 27(1), 7-36.

Bohn. (1998). The behavior of US public debt and deficits. Quarterly Journal of Economics, 113(3), 949-963. https://doi.org/10.1162/003355398555793.

Brueckner. (2003). Strategic interaction among governments: An overview of empirical studies. International regional science review, 26(2), 175-188. https://doi.org/10.1177/0160017602250974.

Campbell John. (2001). Institutional analysis and the role of ideas in political economy. The Rise of Neoliberalism and Institutional Analysis, pp 159-190. https://doi.org/10.2307/j.ctv301g8t.13

Carroll. (2010). Corporate Taxes and Wages: Evidence from the 50 States. Tax Foundation Working Paper 8. Retrieved from https://taxfoundation.org/corporate-taxes-and-wagesevidence-50-states

Chirinko \& Wilson. (2006). State Investment Tax Incentives: What Are the Facts? Federal Reserve Bank of San Francisco Working Paper 2006-49. https://doi.org/10.24148/wp2006-49.

Chirinko \& Wilson. (2017). Tax Competition Among U.S. States: Racing to the Bottom or Riding on a Seesaw? Federal Reserve Bank of San Francisco Working Paper No. 2008- 
03. https://doi.org/10.24148/wp2008-03.

Chodorow-Reich, L., Feiveson, Z., Liscow \& W. G. Woolston. (2012). Does state fiscal relief during recessions increase employment? Evidence from the American Recovery and Reinvestment Act. American Economic Journal: Economic Policy, 4(3), 118-145. https://doi.org/10.1257/pol.4.3.118

Clausing Kimberly. (2012). In Search of Corporate Tax Incidence. Tax Law Review Volume 65. https://doi.org/10.2139/ssrn.1974217

Cloyne James. (2013). Discretionary Tax Changes, and the Macroeconomy: New Narrative Evidence from the United Kingdom. American Economic Review, 103(4), 1507-28. https://doi.org/10.1257/aer.103.4.1507

Devereux, B. Lockwood \& M. Redoano. (2008). Do countries compete over corporate tax rates? Journal of Public Economics, 92(5-6), 1210-1235. https://doi.org/10.1016/j.jpubeco.2007.09.005

Easterly \& Rebelo (1993). Fiscal policy and economic growth. Journal of Monetary Economics, 32(3), 417-458. https://doi.org/10.1016/0304-3932(93)90025-b_

Gale G., \& Samwick A. (2017). Effects of Income Tax Changes on Economic Growth. The Economics of Tax Policy. https://doi.org/10.1093/acprof:oso/9780190619725.003.0002

Goolsbee Austan. (2004). The impact of the corporate income tax: evidence from state organizational form data. Journal of Public Economics, 88(11), 2283-2299. https://doi.org/10.1016/j.jpubeco.2003.05.002

Harberger Arnold C. (1962). The Incidence of the Corporation Income Tax. Journal of Political Economy, 70(3), 215-240. https://doi.org/10.1086/258636

Hassett \& Mathur. (2006). Taxes and Wages. American Enterprise Institute for public policy research. http://pcsi.pa.go.kr/files/20060706_TaxesandWages.pdf

Hassett, Jason C., \& G. Hubbard. (1996). Tax Reforms and Investment: A Cross-Country Comparison. Journal of Public Economics, 62(1-2), 237-273. https://doi.org/10.1016/0047-2727(96)01580-0

Ito T., \& O. Krueger. (1992). The political economy of tax reform. NBER-East Asia Seminar on Economics, Volume 1. University of Chicago Press. https://doi.org/10.7208/chicago/9780226387000.001.0001

Kahn \& Whited. (2017). Identification Is Not Causality, and Vice Versa. The Review of Corporate Finance Studies, 7(1), 1-21. https://doi.org/10.1093/rcfs/cfx020

Klassen, S.K. Laplante. (2012). Are US multinational corporations becoming more aggressive income shifters? Journal of Accounting Research, 50(5), 1245-1285. https://doi.org/10.1111/j.1475-679x.2012.00463.x

Lee \& Gordon. (2004). Tax structure and economic growth. Journal of Public Economics, 
89(5-6), 1027-1043. https://doi.org/10.1016/j.jpubeco.2004.07.002

Ljungqvist \& Smolyansky. (2014). To cut or not to cut? On the impact of corporate taxes on employment and income. NBER Working Paper 20753. http://dx.doi.org/10.2139/ssrn.2536677_

Mintz \& Smart. (2004). Income shifting, investment, and tax competition: theory and evidence from provincial taxation in Canada. Journal of Public Economics, 88(6), 1149-1168. https://doi.org/10.1016/s0047-2727(03)00060-4

Mintz \& Tulkens. (1986). Commodity tax competition between member states of a federation: Equilibrium and efficiency. Public goods, environmental externalities and fiscal competition, 449-489. https://doi.org/10.1007/978-0-387-25534-7_23

Peters G., (1992). The politics of taxation: A comparative perspective. New York University Press. Retrieved from https://www.amazon.com/Politics-Taxation-ComparativePerspective/dp/1557862117

Pierson K., Hand M., \& Thompson F. (2015). The government finance database: A common resource for quantitative research in public financial analysis. University of Willamette, Government Finance database. https://doi.org/10.1371/journal.pone.0130119

Randolph William C. (2006). International Burdens of the Corporate Income Tax. Congressional Budget Office Working Paper Series. Retrieved from https://cbo.gov/sites/default/files/cbofiles/ftpdocs/75xx/doc7503/2006-09.pdf

Raveendra Batra N. (1975). A General Equilibrium Model of the Incidence of Corporation Income Tax under Uncertainty. Journal of Public Economics, 4(4), 343-360. https://doi.org/10.1016/0047-2727(75)90010-9

Swank \& Steinmo. (2002). The New Political Economy of Taxation in Advanced Capitalist Democracies. American Journal of Political Science, 46(3), 642-655. https://doi.org/10.2307/3088405

Tanzi \& Zee. (2000). Tax policy for emerging markets: developing countries. National Tax Journal, 53(2), 299-322. https://doi.org/10.17310/ntj.2000.2.07

Vartia Laura (2008). How do taxes affect investment and productivity? An industry-level analysis of OECD countries. OECD Economics Department Working Papers. https://doi.org/10.1787/230022721067

Wilson \& Janeba. (2005). Decentralization and international tax competition. Journal of Public Economics, 89(7), 1211-1229. https://doi.org/10.1016/j.jpubeco.2004.08.005

\section{Notes}

Note 1. This represents the rate applied to the highest bracket of corporate profits after the tax Cuts and Jobs Act of 2017. 


\section{MIMacrothink}

Note 2. The literature treats it as a linear tax due to few number of brackets, most corporate profits usually lie in top bracket.

Note 3. Economic Recovery Tax Act in 1981 and Tax Reform Act in 1986.

Note 4. Even though this distinction did not matter much for the qualitative implications of this analysis.

Note 5. This occurs due to several reasons such as the adoption of successive corporate tax changes within the same reform.

Appendix: Note on the effective corporate tax rates

The corporate effective tax rates used in this paper are obtained from Chirinko and Wilson (2006). On top of the statutory corporate income tax, most states provide firms with instruments that reduce the tax burden on profits. Chirinko and Wilson considered the deductibility of federal corporate taxes from state tax liabilities to construct an effective corporate tax variable. While some states allow full deductibility of federal corporate taxes from state taxable income and other allow no deductibility at all, Iowa and Missouri allow only 50\% deductibility. Denoting the provision for federal tax deductibility in state $s$ over period $t$ as $v_{s, t}=\{1.0,0.5,0.0\}$, the effective corporate tax rate in state $s$ in period $t$ is defined by:

$$
\tau_{s, t}^{E, S}=\tau_{t}^{L, S}\left(1-\tau_{s, t}^{E, \mathrm{~F}} v_{s, t}\right)
$$

Where $\tau_{t}^{L, S}$ denotes the statutory corporate tax rate in state $s$ over period $t$ and $\tau_{s, t}^{E, \mathrm{~F}}$ represents the effective corporate tax rate at the federal level over the same period. Considering that in many states the corporate tax schedule is not linear, we measure $\tau_{t}^{L, S}$ with the marginal legislated tax rate for the highest bracket.

Similarly, given that state corporate tax payments are fully deductible from federal tax liabilities, the effective corporate tax rate at the federal level is given by:

$$
\tau_{s, t}^{E, \mathrm{~F}}=\tau_{t}^{L, \mathrm{~F}}\left(1-\tau_{s, t}^{E, \mathrm{~S}}\right)
$$

Using equations (1) and (2), Chirinko and Wilson suggested that the effective corporate income tax rates at the state and federal levels are systematically related. Solving for the effective corporate tax rates respectively at the state and federal levels yields the final expressions:

$$
\tau_{s, t}^{E, \mathrm{~S}}=\frac{\tau_{s, t}^{L, \mathrm{~S}}\left(1-v_{s, t} \tau_{t}^{\mathrm{L}, \mathrm{F}}\right)}{\left(1-v_{s, t} \tau_{s, t}^{\mathrm{LS}} \tau_{t}^{L, F}\right)}
$$




$$
\tau_{s, t}^{E, \mathrm{~F}}=\frac{\tau_{t}^{L, \mathrm{~F}}\left(1-\tau_{s, t}^{\mathrm{L}, \mathrm{S}}\right)}{\left(1-v_{s, t} \tau_{s, t}^{\mathrm{L}, \mathrm{S}} \tau_{t}^{L, F}\right)}
$$

Collecting data on state and federal corporate tax rates along with state provisions regarding federal tax deductibility, we extended the state effective corporate tax series computed by Chirinko and Wilson from 2006 to 2014.

\section{Copyright Disclaimer}

Copyright for this article is retained by the author(s), with first publication rights granted to the journal.

This is an open-access article distributed under the terms and conditions of the Creative Commons Attribution license (http://creativecommons.org/licenses/by/3.0/). 